THE INTERNATIONAL

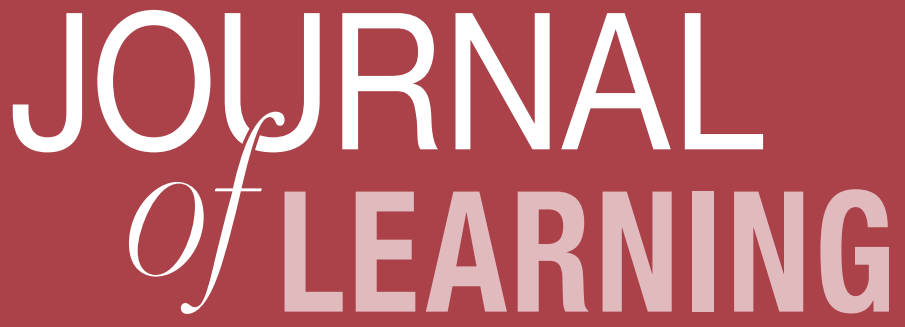

Volume 18, Issue 7

Will We Meet Again?: Examining the Reasons Why Students are Leaving First Year University Courses and Moving Towards an Approach to Stop Them

Ana Lobo 
THE INTERNATIONAL JOURNAL OF LEARNING

http://www.Learning-Journal.com

First published in 2012 in Champaign, Illinois, USA

by Common Ground Publishing LLC

www.CommonGroundPublishing.com

ISSN: $1447-9494$

(C) 2012 (individual papers), the author(s)

(c) 2012 (selection and editorial matter) Common Ground

All rights reserved. Apart from fair dealing for the purposes of study, research, criticism or review as permitted under the applicable copyright legislation, no part of this work may be reproduced by any process without written permission from the publisher. For permissions and other inquiries, please contact

<cg-support@commongroundpublishing.com>.

THE INTERNATIONAL JOURNAL OF LEARNING is peer-reviewed, supported by rigorous processes of criterion-referenced article ranking and qualitative commentary, ensuring that only intellectual work of the greatest substance and highest significance is published.

Typeset in Common Ground Markup Language using CGPublisher multichannel typesetting system

http://www.commongroundpublishing.com/software/ 


\title{
Will We Meet Again?: Examining the Reasons Why Students are Leaving First Year University Courses and Moving Towards an Approach to Stop Them
}

\author{
Ana Lobo, Griffith University, Queensland, Australia
}

\begin{abstract}
Competition for students in a global market is intense. High attrition rates amongst university students are one of the underlying undesirable factors in the marketing mix tertiary institutions use to attract students (Schwartz, 2007). Not surprisingly, in a higher education environment where federal funding arrangements have started to focus on student completions rather than employment, it is essential to determine why students leave. In order to better understand the different dimensions involved in student attrition and retention it is important to determine the salient factors students give for withdrawing from their first-year tertiary courses. Through a review of the international literature, this paper introduces 17 factors why students claim to withdraw from their studies. This paper explores why students abandon their studies, and how to identify at-risk students for preventive intervention.
\end{abstract}

Keywords: Student Attrition, University Students, First-year Student Retention, Foreign Language Student Attrition, University Withdrawal

\section{Introduction}

$\mathrm{F}$

OR OVER 40 years researchers have been discussing the issue of student attrition and retention and trying to deliver answers as to why students, and more specifically first-year students, withdraw from their university courses. There is a large body of research studies from higher education that discusses the factors that affect retention. These studies have investigated first-year performance and persistence in tertiary education, but their findings show that there is not one simple reason for students' withdrawing from tertiary education: rather, a large combination of factors ultimately contributes to student withdrawal (Harvey, Drew, \& Smith, 2006).

This paper aims to look at the most important factors leading to the withdrawal of firstyear students overall, with a special emphasis on those students taking foreign language classes, by examining the international literature in the area of student retention and attrition. It also takes a brief look at how at-risk students may be discovered and encouraged to stay at university using a prognostic approach to retention.

Educational institutions are increasingly held accountable for retention rates by state governments, policy makers, business leaders, consumer advocates, parents and students. Some of these bodies have direct accountability measures that associate funding with retention rates (Roman, 2007). It has been well documented that students are most likely to withdraw from university during their first year of study, therefore the focus of this paper is on not only determining why students are leaving (Darlaston-Jones et. al, 2003), but also how to determine the signs of at-risk students in order to offer them the help and encouragement needed in order to stay in their courses. Maintaining first-year students in their courses could 
ultimately establish their continuation at university to finish the rest of their degree (DarlastonJones et. al, 2003). Student retention has been identified for decades as an important measure of institutional effectiveness. This is because student enrolments represent and can be translated into amounts of revenue for educational institutions (Wild \& Ebbers, 2002). Although tertiary student attrition and retention are not new areas of research, their literature shows mixed views as to the precise meaning of both terms. According to Riggert, Boyle, Petrosko, Ash, and Rude-Parkins (2006), defining retention has created some notable difficulties for researchers and educational institutions alike. Disagreement about whether to define retention as "re-enrolment from year to year" or from "semester to semester" has been notable and definitional inconsistencies have been a continuing shortcoming in the empirical literature (Riggert et al., 2006).

For the purposes of this study, the definitions of retention and attrition to be used are most similar to those suggested by the Department of Education, Science and Training or DEST (2004). DEST defines student retention as the students enrolled in one year of a course or degree who are enrolled in the subsequent year. The definition used for attrition will also be quite similar to the one used by DEST (2004), which describes student attrition as the measure of the proportion of students in a particular year who neither graduate nor continue studying in an award course (official university course) at the same institution the following year.

\section{Factors Contributing to Student Withdrawal}

According to Marginson (2006), the global context of higher education is a fast moving fast changing and uneven environment, criss-crossed by shifting relations of collaboration, competition and hierarchy. The reality is that universities are now as competitive as any business and compete for students, staff, research grants, industry contracts and donations and recent research shows that it is actually much cheaper to retain a student than to recruit a new one (Schwartz, 2007). As a result of the intense competition felt in the US, Europe, Australia and elsewhere, universities must actively promote themselves in order to succeed (Havas, 2009). In terms of higher education choices, a university with a high attrition rate is not a desirable university to attend, even according to the universities themselves (Schwartz, 2007). Put simply, with federal funding arrangements starting to focus on student completions rather than employment, there is now a trend for universities to investigate the reasons for student withdrawal in Australia (Darlaston-Jones et al., 2003).

In order to better understand the different dimensions of the issue of student attrition and retention it is important to identify which are the most common factors that students give for withdrawing from their first-year tertiary courses and according to the literature, there are 17 factors why students in general seem to withdraw from their studies. These factors can apply to students in all disciplines; however, the $17^{\text {th }}$ factor is specific to those studying in foreign language courses. Ideas for identifying and retaining students will also be discussed after this section.

1. Student expectations and perceptions of university life and study

There is a growing body of literature that suggests students are often unaware of the demands of higher education in terms of its workload, their independent learning and access to academic and support resources (Darlaston-Jones et al., 2003; Peel, 2000; 
Yorke, 2000). Based on research, student expectations of higher education do seem to be changing (McInnis, James, \& Hartley, 2000). Overall, there is not a substantial amount of literature about how students envisage university life and how these preconceptions may shape their experience after enrolment. However, the role that university marketing can play has been discussed recently in the Australian media (Schwartz, 2007). It is unclear whether universities may be misleading students as to what to expect with their enthusiastic marketing, or the students enter university with already perceived notions that could lead them to disappointment (Schwartz, 2007). More recently, research has shown that there can be a link made between student expectations and student performance and that the consequence of unmet expectations can be disengagement, nonattendance and withdrawal (Bordia, 2011; N. Zepke \& Leach, 2010). This point illustrates how influential the expectations of students can be to their continuation in a course or university degree, even if some students believe they do not have many.

\section{Social and academic student integration}

Students can feel isolated by the university experience and find it hard to integrate. New experiences, new people and a different way of life can also add to the stress of a first-year student. However, can social and academic integration driven by the university help? Studies carried out on the topic show that many researchers seem to think that social and academic integration play a major part in whether students decide to continue at university or withdraw (Beil, Reisen, Zea, \& Caplan, 1999; Tinto, 1975, 1987, 1993, 1997). Research conducted by Krause (2005) in Australia, discusses that developing a sense of belonging and involvement in the life of the university is a critical feature of the successful first year experience. Tinto, whose work in the area of student retention and attrition spans over three decades, described academic integration as "the full range of individual experiences which occur in the formal and informal domains of the academic systems of the university" (Tinto, 1993, p. 118). He argued that the academic and social experiences during the first few weeks of university study had a strong effect on the integration of first year students into the social and academic communities of the university.

As a result of this research it can be understood that social and academic student integration may play an important part in the university life and wellbeing of students and as a result could lead students to withdraw from their studies.

\section{Teaching and learning styles}

Braxton, Milem, and Sullivan (2000) researched the impact of teaching styles on student departure. They argue that when students are engaged in active learning they seem to be more likely to view their university experience as personally rewarding, and as a result invest the psychological energy needed to establish memberships in the social communities of the university. This social interaction can lead to better social and academic integration. Their study also shows that the lack of active learning could influence student departure decisions, or more specifically, that faculty classroom behaviours play a role in the student departure process (Braxton et al., 2000). More recently, it has been found that teachers play a much more important role than first realised in preventing student attrition (ALTC, 2009). The results of data collected from almost 1400 students around Australia found that factors such as relationships with teaching staff, subject 
interactivity, and work-integrated learning all affected the successful progression of students (ALTC, 2009). The research also found that relationships with teaching staff within the learning environment have been proven to enhance progression for successful students because they make help-seeking less daunting and encourage academic achievement (ALTC, 2009). This research clearly shows that not all teaching styles will be suitable for all students and this factor should be taken into account when assessing student attrition numbers.

\section{4. $\quad$ Assessment strategy used in courses}

Formative assessment is highly important to student learning and should go hand-inhand with summative assessment as a tool to help students learn and ultimately judge their achievement in any particular course (Yorke, 2001). Yorke advocated the importance of formative assessment and how it might better contribute to student development and retention, particularly in the first year of higher education. Yorke (2001) refers to Tinto's model of institutional departure as showing academic and social experiences as crucial intermediates between students' intentions, goals and commitments at entry to university and the decision whether or not to leave an institution. He believes that formative assessment can contribute to this academic integration modelled by Tinto (1975), particularly as students come to terms with their transition into higher education. He found that, without meaningful formative assessment, academic integration-and hence retention-is put at risk (Yorke, 2001).

\section{Student mentoring}

A study that shows insights into the positive influence that student mentoring programmes could have on student retention was conducted by Sidle and McReynolds (1999). Their longitudinal study explored the relationship between student participation in the institution's freshman year (that is, first year) experience course and student retention leading to success at an American university. Overall, Sidle and McReynolds' study found that the freshman-year experience course had a positive influence on the persistence of some first-year students. They found that the 431 students who enrolled in the course persisted to their second year of study at the university at a higher rate than those students who chose not to enrol in the course. Using the findings from the study as an example, the difference between retaining $63 \%$ of the students, who would otherwise only persist at a rate of $56 \%$, meant that for every 100 students 7 more would return to the institution, continue their enrolment and continue to pay tuition and fees (Sidle \& McReynolds, 1999). Research by Walker and Taub (2001) has also shown that mentoring can have a positive impact on first-year students in particular, giving them a sense of personal significance and validation, which allows them to feel more integrated into the fabric of the university and therefore in that way promoting student retention. Although this factor has not been researched on a larger scale, it is still significant to the issue of student retention as it has shown that it works at retaining students. More research into this factor may show that mentoring should be used, especially with first-year students in more universities. 
6. Students' living arrangements (on campus, with friends, at home, among others)

Beekhoven, De Jong, and Van Hout (2004) investigated students' living arrangements and the impact that living out of home had on their university integration and their study progress in the Netherlands. His research found that students living independently in their first year of study were predominantly studying courses from the social sciences and humanities. Overall, the study showed that students living independently in rooms devoted less time to study. It also showed that living independently did not have a positive effect on the integration of first-year students. On the contrary, it had a definite negative effect on the situation of students attending a university of professional education, or what we in Australia would call professional or technical colleges. The main reasons found for the negative effect living arrangements had on first-year students were the challenges these students faced dealing with fitting in with other students, as they were all there independently.

\section{Student age}

Adult students or mature aged students are often juggling competing demands on their time from study, family, work and other commitments (Wonacott, 2002). Adults are often affected by situational factors out of their control, and likewise dispositional factors such as expectations, self-esteem, level of family support, and past educational experience can be barriers to participation (Wonacott, 2002). For domestic, first-year students, the factors that seem to be of central importance to retention are student preparedness, compatibility of course choice to their career outcomes, and time of exit from the university in question (that is, before it is too late to get a second chance). In contrast, this same study found that mature aged students are often forced into noncompletion due to external circumstances, such as work and family commitments (Ozga $\&$ Sukhnandan, 1998). As a result, mature aged students were a lot more likely, through external factors, to withdraw from university than younger students.

\section{Student gender}

Gender has often been mentioned as a factor that could contribute to the withdrawal of tertiary students in the US (Bonham \& Luckie, 1993; Tinto, 1975). Most of the initial research into the area of student retention showed that being female was the factor that more often contributed to withdrawal (Astin, 1971; Tinto, 1975). Nowadays, there is more and more evidence that the tables have been turned. Being a female is no longer a factor that contributes to withdrawal, as recent research has begun to show male attrition rates are much higher than those for females (Henry, 2007). In fact, recent research found that women are better at staying in their courses of study than men and international female students had the lowest attrition rates of any university students, including undergraduates, postgraduates, and domestic students (Olsen, 2008). In some cases, the dominance of female tertiary students has even begun to be seen as problem, as male students simply do not continue their studies to the same extent females do. There are four studies in particular, conducted at tertiary institutions in the US, the UK and New Zealand, that look into gender as a factor contributing to the withdrawal of students. Research by Bonham and Luckie (1993), Scott (2005), Gabb and Cao (2006) and Bidgood, Saebi, and May (2006) shows that gender, although not such a prevailing factor, is still an important one when considering student attrition. Although initially gender 
was viewed as a negative factor towards women's retention, the trend in tertiary education has now made it a factor mostly influencing men.

\section{Work and issues with employment}

Employment has often come to the surface as an issue which influences the retention of students at university. It is well known that students who have long working hours cannot dedicate as much time to their studies as those who do not work as many hours or at all (Barrett, 2000). Many researchers mention work and issues related to employment as a factor affecting student retention (Blanchard \& Mascetti, 2000; Bonham \& Luckie, 1993; Bradburn, 2002; Johnston, 1997; Lee, 1996; Long, Ferrier, \& Heagney, 2006; Scoggin \& Styron, 2006). Their research studies, carried out in the US, the UK and Australia, show that students who withdrew from university felt that work contributed to their withdrawal. Full-time employment seems to influence students more than part-time employment. In addition, studies pointed out that the predicament of combining work and study seems more prevalent to older students with families for whom work is not optional (Long et al., 2006). These students often report that their employment is a main source of income; understandably they cannot stop work in order to study and therefore may require some form of government support to continue studying (Long et al., 2006). Broadbridge and Swanson (2005) researched the impact of part-time work on students' adjustment to university life in the UK. They found that currently, increasing numbers of students are likely to combine study with term-time employment (that is, employment during the academic semester). They believe that an understanding of students' work patterns, in relation to characteristics of individual students, may help reduce attrition rates. This understanding could be beneficial to students, higher education establishments and employers in the long-term (Broadbrige \& Swanson, 2005), because this information could aid higher education policy makers in improving course organisation, and as an outcome, help students to continue studying in these courses due to the flexibility made available.

\section{Financial concerns}

Financial concerns have for a long time been a worrying factor for university students and there is no denying that many students do suffer from serious financial hardship while attending university. Generally, non-traditional students have greater financial obligations than younger students, although all students can potentially be affected by financial issues (Jeffreys, 2004). The term non-traditional students, or mature aged students as is more often used in Australia, refers to students between the ages of 25 and 60 , working in a part- or full-time capacity, and attending a university facility to undertake a part-time or full-time study program (Wylie, 2005).

In Australia, gender, socio-economic status, Aboriginality, and ethnicity/culture are common grouping categories for disadvantage (Leder \& Forgasz, 2004). It is important to point out that mature age, however, is not a recognised category of disadvantage, even though the lives and responsibilities of these students are often more complex than those of their younger peers (Leder \& Forgasz, 2004). Since 1993, many studies on student retention have identified that financial issues and concerns are a major influence on the retention of tertiary students (Bidgood, Saebi, \& May, 2006; Blanchard \& Mascetti, 2000; Bonham \& Luckie, 1993; Bradburn, 2002; Elliott, 1997; Glogowska, 
Young, \& Lockyer, 2007; Glossop, 2002; Hoyt, 1999; Johnston, 1997; Lee, 1996; Long et al., 2006; Scoggin \& Styron, 2006; Wilcox, Winn, \& Fyvie-Gauld, 2005; Yorke, 2000). These studies pointed out that financial issues are detrimental to students' progress at university and that the outcome of financial problems for students is often university withdrawal. Therefore, this is one of the major factors contributing to attrition.

\section{Student lack of preparation for university life and study}

The relationship between preparedness and student withdrawal has been previously documented by Yorke (2000), who describes six elements contributing most to the inability of students in the UK to cope with the demands of the university they enrolled in, due to their lack of preparation for university life and study. These elements are stress-related issues, difficulties in integrating, too heavy workload, lack of study skills, lack of personal support from fellow students, and insufficient academic progress. As a result, the lack of student preparation for university life means that these factors can all directly contribute to student withdrawal (Yorke, 2000). Previous studies conducted in Australia, the UK and the US (Elliott, 1997; Hoyt, 1999; Long et al., 2006; Wilcox et al., 2005) have shown that students do withdraw from university due to a lack of preparation. However, research by Goodman and Pascarella's suggests that first-year seminars provide positive benefits to all categories of students and that these seminars are a good all-purpose intervention to increase persistence from first to second year. Academically, students who participate in first-year seminars have more positive perceptions of themselves as learners (Goodman \& Pascarella, 2006). Therefore, induction programmes to universities can help student retention. Interestingly, in the UK, Yorke and Longden (2006) also recently found that the more students know about their institutions and courses before enrolling, the less likely they will withdraw: $40 \%$ of those with little to no prior knowledge of their program considered withdrawing, to be compared with only $25 \%$ of better informed peers.

\section{Family responsibilities and obligations}

Family obligations have often been the reason why some students decide to withdraw from their studies. Mature age students, in particular, seem to have an array of family responsibilities when commencing university. Many of these responsibilities could impact on their ability to dedicate the appropriate amount of time to their studies. Overall, research on retention factors affecting students found that family obligations were a serious issue. Several researchers (Blanchard \& Mascetti, 2000; Bonham \& Luckie, 1993; Bradburn, 2000; Glossop, 2002; Hoyt, 1999; Long et al., 2006) mentioned family obligations as important factors contributing to the withdrawal of students in the US and the UK. Family responsibilities and obligations can vary. However, they generally involve taking care of children and/or elderly parents (Bonham \& Luckie, 1993).

\section{Dissatisfaction with the university}

Several studies from the US and the UK have pointed out "university dissatisfaction" as a factor that led students to withdraw (Bidgood et al., 2006; Bradburn, 2002; Lee, 1996; Long et al., 2006; Yorke, 2000). Dissatisfaction with the university in question has recently become a serious issue for tertiary institutions. The correlation between 
student dissatisfaction and student expectations is becoming more visible and both are extremely important and relevant to student retention (Lowe \& Cook, 2003). Unfortunately, most of the research into the factors concerning student attrition has not investigated in depth the individual reasons that result in student dissatisfaction. As a consequence, this often transmits the message that the students are dissatisfied with the university as a whole, which may not be the case. Therefore, more research is needed into this area.

\section{Academic difficulties}

Academic difficulties have long been a concern for university scholars and administrators, as research has shown that a lack of academic integration can lead to student attrition (Bean, 1983; Tinto, 1975, 1987, 1993, 1997). Academic difficulties are also a difficult factor to investigate for universities, as research shows students do not always like to admit to having difficulties with their studies (Scoggin \& Styron, 2006). Often, the label "academic difficulties" is perceived as carrying negative connotations and students simply may not want to suggest that they are academically incapable of remaining at university (Scoggin \& Styron, 2006). According to a study by Gifford, Perriot-Briceño, and Mianzo (2006), the overall Grade Point Average (GPA) of a student is an important predictor of retention. In their study, they found that students who obtained higher GPAs were a lot more likely to continue at university than those who obtained a lower score. Recent research has shown that academic aid improves the university completion rates of students, especially females (Glenn, 2007). In fact, Glenn reports in the context of a Canadian University that when combined with financial aid, academic aid and tuition not only improves the retention rates of the students, but it also improves their overall success at university. Other studies, from the US, UK and Australia (Bradburn, 2002; Elliott, 1997; Gifford et al., 2006; Glogowska et al., 2007; Glossop, 2002; Hoyt, 1999; Johnston, 1997; Long et al., 2006; Wilcox et al., 2005; Yorke, 2000), also show that academic difficulties are an important factor contributing to student retention.

\section{Health and personal reasons}

Health issues are a big concern for students because health problems often contribute to the withdrawal of students from university. Although they can take on many different variables, health problems can sometimes lead to a lack of academic integration, leading in turn to academic difficulties. Research in this area (Glogowska et al., 2007; Glossop, 2002; John- ston, 1997; Long et al., 2006; Scoggin \& Styron, 2006) shows that students who are suffering from health problems normally withdraw from university due to this factor. Many researchers (Bradburn, 2002; Elliott, 1997; Glogowska et al., 2007; Johnston, 1997; Wilcox et al., 2005) have found that personal reasons often affect student retention. Therefore, by recognising that students have identified personal and health problems as leading reasons for their withdrawal, both the counselling and health services at the university could play an important role in assisting students to manage these problems. In order to do this however, there is a need to find out about the student and any relevant events affecting them. 


\section{Course or Programme unsuitability}

Several researchers (Bidgood et al., 2006; Elliott, 1997; Johnston, 1997; Wilcox et al., 2005; Yorke, 2001; N. Zepke, Leach, \& Prebble, 2006) found that students believed that the course not "suiting" them led to their withdrawal. Students may often start degrees and courses thinking that they are prepared and willing to take on the challenges and requirements of each. However, this can often be discarded when students begin the courses and discover that they are far removed from what they expected, or that they do not like the content or other aspects of the course, or they simply change their mind. Although there are many reasons a course may not have suited a student, in all the research found in this area, the reasons why the students thought that the course did not suit them were not documented. This makes it difficult to determine the exact causes for lack of compatibility between a student and the course they are studying.

\section{Learning anxiety (in particular, foreign language learning anxiety).}

The $17^{\text {th }}$ factor needs particular mention. Learning anxiety has previously been identified as a problem that students studying mathematics, statistics and science have faced (Ashcraft \& Kirk, 2001; Ma \& Xu, 2003). Mathematics anxiety, possibly the most documented of the three, refers to the feelings of tension and anxiety that interfere with the manipulation of numbers and the solving of mathematical problems in a wide variety of ordinary life and academic situations (Sherman \& Wither, (2003). In the same vein, statistics anxiety is experienced by college students who have a limited background in quantitative research and statistics and who are enrolled in a course that requires that they analyse data utilizing statistical concepts and techniques, whereas science anxiety is believed to affect science students during science classes and particularly during exams, even if they are calm and productive in non-science classes, including mathematics (Collins \& Onwuegbuzie, 2006; Mintzes \& Leonard, 2006). However, since the late 1980 s, literature in the area of second language (L2) learning has discussed what is referred to as "foreign language learning anxiety" and how this problem could affect the retention levels of students studying in language classes (Horwitz, Horwitz, \& Cope, 1986). This factor is the only one on the list that is directly related to the retention of students studying in language classes.

In light of the international literature available on the topic of student retention and attrition, it could be surmised that there were 17 main factors that contributed to the withdrawal of students from university courses internationally. These factors were considered general factors that could affect students studying in any discipline. One of the major findings in the literature review was the lack of research into the issue of student attrition in foreign language courses. It is strongly recommended that further studies into foreign language student retention be conducted as the number of year 12 students in Australia currently learning a language is approximately 13\% (Mueller, 2003). Which such small numbers possibly continuing their language studies at university, it is crucial that all the students who begin learning a language continue in the course.

It is important to mention however, that some factors, such as expectations and financial difficulties, which have been heavily researched, may be more influential to student retention than other factors, such as student living arrangements and mentoring, which have not been researched and analysed in as much detail. With that in mind, it is clearly very important 
that these issues continue to be researched. History has shown that student retention is not an issue that is going away and with different student cohorts, different problems may arise. Putting these findings into a useful context is also very important. As we now have a clearer idea of the factors influencing students' decisions to withdraw there need to be steps put in place to ensure students are receiving the information and support they need. These measures must come quite early in the academic life of the student in order to ensure the best results.

\section{How At-risk Students Can Be Identified and Retained}

The issue of student attrition has been researched and analysed for over 40 years. During this time many effective attrition models have been developed and theories established, all aiming to clarify why student attrition occurs and what can be done to remedy it. However, the real complexity associated with student attrition is the fact that it is often found to be out of the control of the institutions that experience it. Taking this fact into consideration, it is fundamental to ensure that students who are enrolled in a course are aware of the support available to them when at university. Tutors, lecturers and course convenors have a responsibility not only to educate the students in their courses, but also to offer additional academic support to these students as required and encourage them to seek other forms of support when needed. Knowing that there are 17 potential factors which can lead students to withdraw from their studies, some of which are out of the university's control, can make student attrition a serious challenge. According to the international literature available on retention and attrition, a number of student retention and attrition models were developed between the 1970s and 1990s (Lobo \& Poyatos Matas, 2010b). Most of those models varied in terms of elements included, participating students, and final hypotheses. However, the models had one commonality: they each studied student retention and attrition from the stage the student had left. In a sense, these models all aimed to discover the factors why students were withdrawing from their studies and perhaps then offer ways in which to combat these withdrawal factors, even if each model did achieve this in a different way. The most well known is the Student Integration Model developed by Tinto in 1975 (Lobo \& Poyatos Matas, 2010b). Since then, other models have fallen mainly into two distinct categories: trying to improve Tinto's original model, or trying to refute it. The literature showed the lack of retention and attrition models that tackled the issue of student withdrawal from the beginning of the course, that is, before students had withdrawn and as a result they were not actively retaining any students in these courses.

In order to combat this problem an approach to language student retention has been developed. A prognostic stance that uses the First Year Student Survey (FYSS) as one of its main instruments to identify if students are at risk before they withdraw from a language course, is at the heart of this approach (Lobo \& Poyatos Matas, 2010a). The approach uses two tools, the First Year Student Survey and the First Year Student Support Sheet. It is distributed by the teacher of the course during the first week of classes. The aim of the survey is to identify those students at risk of withdrawing from the foreign language course at the very beginning of the semester. To determine which students are at risk is easy as the survey scores showed that students who had higher scores were at a lower risk of withdrawing and those with low scores had a higher chance of withdrawing. The trials of the prognostic approach and its implementation and evaluation in 2008, showed that the FYSS was successful in identifying students at risk of withdrawing from a foreign language university course 
(Lobo \& Poyatos Matas, 2010a). Although proving to be successful in its pilot and first implementation stages, the tool still needs some refining and there is a need to also to trial the prognostic approach with other disciplines, with other languages and with larger numbers of students before it can be functioning on a completely accurate basis. However, putting into action an approach that encourages students to seek support and can identify those students at-risk of withdrawing at an early stage during the first year of a student's tertiary education could go a long way in achieving the aim of retaining more first-year students overall. 


\section{References}

Ashcraft, M. A., \& Kirk, E. P. (2001). The relationships among working memory, math anxiety, and performance. Journal of Experimental Psychology: General 130(224).

Astin, A. (1971). Predicting Academic Performance in College. Selectivity Data for 2300 American Colleges. New York: The Free Press.

Barrett, S. (2000). The work/study dilemma: A pilot study. International Education Journal, 1(2), $127-137$.

Bean, J. (1983). The Application of a Model of Turnover in Work Organizations to the Student Attrition Process. The Review of Higher Education, 6(2), 129-148.

Beekhoven, S., De Jong, U., \& Van Hout, H. (2004). The impact of first-year students' living situation on the integration process and study progress. Educational Studies, 30(3), 277-289.

Beil, C., Reisen, C., Zea, M., \& Caplan, R. (1999). A Longitudinal Study of the Effects of Academic and Social Integration and Commitment on Retention. NASPA Journal, 37(1), 376-384.

Bidgood, P., Saebi, N., \& May, S. (2006). Influences on student withdrawal from further education: a case study. Journal of Vocational Education and Training, 58(2), 223-236.

Blanchard, W., \& Mascetti, K. (2000, April 13-14). Tracking Down Non-Returning students at an Urban University: Method and Results. Paper presented at the Annual Meeting of the Alabama Association for Institutional Research, Alabama.

Bonham, L. A., \& Luckie, J. I. (1993). Taking a break in schooling: Why community college students stop out. Community College Journal of Research and Practice, 17(3), 257-270.

Bordia, S., Wales, L., Gallois, C. \& Pittam, J. (2011). Antecedents and consequences of TESOL student expectations. Australian Review of Applied Linguistics, 31(2), 15.11-15.18.

Bradburn, E. (2002). Short-term Enrolment in Postsecondary Education: Student background and Institutional Differences in Reasons for Early Departure, 1996-98. Education Statistics Quarterly, 4(4).

Broadbrige, A., \& Swanson, V. (2005). Earning and learning: how term-time employment impacts on students' adjustment to university life. Journal of Education and Work, 18(2), 235-249.

Collins, K., \& Onwuegbuzie, A. (2006). The Relationship Between Reading Ability and Statistics Anxiety Among African-American Graduate Students: Implications for the Teaching and Learning of Statistics. Paper presented at the $7^{\text {th }}$ International Conference on Teaching Statistics, Bahia, Brazil.

Darlaston-Jones, D., Pike, L., Cohen, L., Young, A., Haunold, S., \& Drew, N. (2003). Are they being served? Student Expectations of Higher Education. Issues in Educational Research, 13.

DEST. (2004). Higher Education Attrition Rates 1994-2002: A Brief Overview Retrieved $12^{\text {th }}$ April, 2005, from <http://www.dest.gov.au/NR/rdonlyres/8A245011-4F59-4D99-9D97A1AD89D0C669/1043/1.pdf>.

Elliott, J. (1997, February 1997). Early student withdrawal: The reasons students give for leaving the university. Paper presented at the 6th Annual Teaching Learning Forum, Murdoch University: Perth

Gabb, R., \& Cao, Z. (2006). Patterns of Progress and Attrition in Commencing Higher Education Students at Victoria University. Melbourne: Postcompulsory Education Centre, Victoria University

Gifford, D., Perriot-Briceño, J., \& Mianzo, F. (2006). Locus of Control: Academic Achievement and Retention in a Sample of University First-Year Students. Journal of College Admission (191), 18-26.

Glenn, D. (2007, Jan 12). Study Finds Mix of Academic and Financial Aid Improves Student Retention, The Chronicle of Higher Education, p. 18.

Glogowska, M., Young, p., \& Lockyer, L. (2007). Should I go or should I stay? Active Learning in Higher Education, 8(1), 63-77. 
Glossop, C. (2002). Student Nurse Attrition: use of an exit-interview procedure to determine students' leaving reasons. Nurse Education Today, 22, 375-386.

Goodman, K., \& Pascarella, E. (Producer). (2006, 23 May 2007). First-Year Seminars Increase Persistence and Retention: A Summary of the Evidence from How College Affects Students. Peer Review. Retrieved from http://proquest.umi.com/pqdweb?did=1089310231 $\&$ sid $=6 \&$ Fmt $=3 \&$ clientld $=13713 \&$ RQT $=309 \&$ VName $=$ PQD

Harvey, L., Drew, S., \& Smith, M. (2006). The first year experience: a review of literature for the Higher Education Academy: Centre for research and evaluation: Sheffiled Hallam University.

Henry, J. (2007, 07 July). Worry over girls' dominance at university, Sunday Telegraph. Retrieved from http://www.telegraph.co.uk/news/main.jhtml?xml=/news/2007/07/08/nedu208.xml

Horwitz, E., Horwitz, M., \& Cope, J. (1986). Foreign Language Classroom Anxiety. The Modern Language Journal, 70(2), 125-132.

Hoyt, J. (1999). Remedial education and student attrition. Community College Review, 27(2), 1-72.

Jeffreys, M. R. (2004). Nursing Student Retention. Understanding the process and making a difference. New York: Springer Publishing Company.

Johnston, V. (1997). Why do first year students fail to progress to their second year? Paper presented at the BERA Annual Conference, University of York.

Leder, G., \& Forgasz, H. (2004). Australian and international mature students: the daily challenges. Higher Education, Research and Development, 23(2), 183-198.

Lee, M. (1996). Student Retention Survey: Why Students Did Not Return, Spring Semester 1994. In O. o. I. R. a. Planning (Ed.). Valhalla, NY: Westchester Community College.

Lobo, A., \& Poyatos Matas, C. (2010a). Towards the development of a prognostic approach to Student retention in foreign language classes. International Journal of Learning, 17(11), 305-316.

Lobo, A., \& Poyatos Matas, C. (2010b). War of Attrition: A Prognostic Remedial Approach to Student Retention. Germany: Lambert Academic Publishing.

Long, M., Ferrier, F., \& Heagney, M. (2006). Stay, play or give it away? Students continuing, changing or leaving university study in their first year Retrieved $28^{\text {th }}$ March, 2007, from http://www.dest.gov.au/sectors/higher_education/publications_resources/profiles/stay_ play_giveaway.htm\#authors

Lowe, H., \& Cook, A. (2003). Mind the Gap: are students prepared for higher education? Journal of Further and Higher Education, 27(1), 53-76.

Ma, X., \& Xu, J. (2003). The causal ordering of mathematics anxiety and mathematics achievement: a longitudinal panel analysis Journal of Adolescence Volume 27(Issue 2), 165-179

Marginson, S. (2006). Australian universities in the global context. Paper presented at the Financial Review Higher Education Summit, Sydney.

McInnis, C., James, R., \& Hartley, R. (2000). Trends in the First Year Experience In Australian Universities. In T. Y. A. Department of Education (Ed.), Trends in the First Year Experience In Australian Universities. Melbourne: Centre for the Study of Higher Education.

Mintzes, J., \& Leonard, W. (2006). Handbook of College Science Teaching: Theory, Research and Practice. Chicago: NSTA Press.

Mueller, F. (2003). Learning languages in Australia-too much like hard work?. Curriculum Leadership, 2.

Ozga, J., \& Sukhnandan, L. (1998). Undergraduate Non-Completion: Developing an Explanatory Model. Higher Education Quarterly, 52(3), 316-333.

Peel, M. (2000). Nobody cares: The challenge of isolation in school to university transition. Journal of Institutional Research, 9(1), 22-34.

Roman, M. (2007). Community College Admission and Student Retention. Journal of College Admis$\operatorname{sion}(194), 18-23$.

Schwartz, S. (2007). Sell yourself but stick to the facts, The Australian, p. 29.

Scoggin, D., \& Styron, R. (2006). Factors associated with student withdrawal from community college. The Community College Enterprise, 12(1), 111-125. 
Scott, D. (2005). Retention, Completion and Progression in Tertiary Education in New Zealand. Journal of Higher Education, 27(1), 3-17.

Sherman, B., \& Wither, D. (2003). Mathematics Anxiety and Mathematics Achievement. Mathematics Education Research Journal, 15(2), 138-150.

Sidle, M., \& McReynolds, J. (1999). The Freshman Year Experience. NASPA Journal, 36(4), 288-300.

Tinto, V. (1975). Dropout from Higher Education: A theoretical synthesis of recent research Review of Educational Research, 45, 89-125.

Tinto, V. (1987). Leaving College: Rethinking the causes and cures of student attrition. Chicago: The University of Chicago Press.

Tinto, V. (1993). Leaving College: Rethinking the causes and cures of student attrition $\left(2^{\text {nd }}\right.$ ed.). Chicago: University Press.

Tinto, V. (1997). Classrooms and Communitites. The Journal of Higher Education, 68(6), 599-624.

Wilcox, P., Winn, S., \& Fyvie-Gauld, M. (2005). "It was nothing to do with the university, it was just the people": the role of social support in the first-year experience of higher education. Studies in Higher Education, 30(6), 707-722.

Wild, L., \& Ebbers, L. (2002). Rethinking student retention in community colleges. Community College Journal of Research and Practice, 26(6), 503-519.

Wonacott, M. E. (2002). Adult students: recruitment and retention. Australian Journal of Career Development, 11(1), 36-38. Retrieved from http://search.informit.com.au/fullText;dn= 115898; res=AEIPT

Wylie, J. (2005). Non-Traditional Student Attrition in Higher Education: A Theoretical Model of Separation, Disengagement then Dropout. Paper presented at the Association for Active Educational Researchers, Parramatta.

Yorke, M. (2000). The Quality of the Student Experience: what can institutions learn from data relating to non-completion? Quality in Higher Education, 6(1), 61-75.

Yorke, M. (2001). Formative Assessment and its Relevance to Retention. Higher Education Research and Development 20(2), 115-126.

Zepke, N., \& Leach, L. (2010). Improving student engagement: Ten proposals for action. Active Learning in Higher Education, 11(3), 167-177.

Zepke, N., Leach, L., \& Prebble, T. (2006). Being learner centred: one way to improve student retention? Studies in Higher Education, 31(5), 587-600.

\section{About the Author}

Dr. Ana Lobo

Ana has been conducting research and teaching Spanish and English at Griffith University for over eight years. As well as teaching, Ana is a professional translator closely affiliated with AUSIT. She was nominated for a Griffith University Teaching Excellence Award, for her contribution to language teaching, in 2006 and 2007. Her research interests are in the areas of student attrition and retention, English as a second language, second language teaching and learning and the practice of translation and interpreting. 


\section{JOURRNAL Of LEARNING}

\section{Editors}

Mary Kalantzis, University of Illinois, Urbana-Champaign, USA.

Bill Cope, University of Illinois, Urbana-Champaign, USA.

\section{Editorial Advisory Board}

Michael Apple, University of Wisconsin, Madison, USA.

David Barton, Lancaster University, Milton Keynes, UK.

Mario Bello, University of Science, Cuba.

Manuela du Bois-Reymond, Universiteit Leiden, Leiden, The Netherlands.

Bill Cope, University of Illinois, Urbana-Champaign, USA.

Robert Devillar, Kennesaw State University, Kennesaw, USA.

Daniel Madrid Fernandez, University of Granada, Spain.

Ruth Finnegan, Open University, Milton Keynes, UK.

James Paul Gee, University of Wisconsin, Madison, USA.

Juana M. Sancho Gil, University of Barcelona, Barcelona, Spain.

Kris Gutierrez, University of California, Los Angeles, USA.

Anne Hickling-Hudson, Queensland University of Technology, Kelvin Grove, Australia.

Roz Ivanic, Lancaster University, Lancaster, UK.

Paul James, RMIT University, Melbourne, Australia.

Carey Jewitt, Institute of Education, University of London, London, UK.

Mary Kalantzis, University of Illinois, Urbana-Champaign, USA.

Andeas Kazamias, University of Wisconsin, Madison, USA.

Peter Kell, University of Wollongong, Wollongong, Australia.

Michele Knobel, Montclair State University, Montclair, USA.

Gunther Kress, Institute of Education, University of London, London, UK.

Colin Lankshear, James Cook University, Cairns, Australia.

Kimberly Lawless, University of Illinois, Chicago, USA.

Sarah Michaels, Clark University, Worcester, USA.

Jeffrey Mok, Miyazaki International College, Miyazaki, Japan.

Denise Newfield, University of Witwatersrand, Johannesburg, South Africa.

Ernest O'Neil, Ministry of Education, Sana'a, Yemen.

José-Luis Ortega, University of Granada, Granada, Spain.

Francisco Fernandez Palomares, University of Granada, Granada, Spain.

Ambigapathy Pandian, Universiti Sains Malaysia, Penang, Malaysia.

Miguel A. Pereyra, University of Granada, Granada, Spain.

Scott Poynting, Manchester Metropolitan University, Manchester, UK.

Angela Samuels, Montego Bay Community College, Montego Bay, Jamaica.

Michel Singh, University of Western Sydney, Sydney, Australia.

Helen Smith, RMIT University, Melbourne, Australia.

Richard Sohmer, Clark University, Worcester, USA.

Brian Street, University of London, London, UK.

Giorgos Tsiakalos, Aristotle University of Thessaloniki, Thessaloniki, Greece.

Salim Vally, University of Witwatersrand, Johannesburg, South Africa.

Gella Varnava-Skoura, National and Kapodistrian University of Athens, Greece.

Cecile Walden, Sam Sharpe Teachers College, Montego Bay, Jamaica.

Nicola Yelland, Victoria University, Melbourne, Australia.

Wang Yingjie, Beijing Normal University, Beijing, China.

Zhou Zuoyu, Beijing Normal University, Beijing, China.

Please visit the Journal website at http://www.Learning-Journal.com for further information about the Journal or to subscribe. 


\section{The Learner Community}

This knowledge community is brought together by a common concern for learning and an interest to explore new educational possibilities. The community interacts through an innovative, annual face-to-face conference, as well as year-round virtual relationships in a weblog, peer reviewed journal and book imprint - exploring the affordances of the new digital media. Members of this knowledge community include academics, teachers, administrators, policy makers and other education practitioners.

\section{Conference}

Members of the Learner Community meet at The International Conference on Learning, held annually in different locations around the world, each selected for the particular role education is playing in social, cultural and economic change.

In recent years, the Conference has been held with Universiti Sains Malaysia, Penang, Malaysia in 1999; RMIT University, Melbourne, Australia in 2000; the University of Athens, Spetses, Greece in 2001; Beijing Normal University, Beijing, China in 2002; Institute of Education, London University, London, UK in 2003; Institute of Pedagogical Sciences, Havana, Cuba in 2004; University of Granada, Granada, Spain in 2005; Sam Sharpe Teachers College, Montego Bay, Jamaica in 2006; University of the Witwatersrand, Johannesburg, South Africa in 2007; the University of Illinois, Chicago, USA in 2008; the University of Barcelona, Spain in 2009; Hong Kong Institute of Education, Hong Kong in 2010; and the University of Mauritius, Mauritius in 2011. In 2012 the Conference will be held at The Institute of Education, University of London, London, UK.

Our community members and first time attendees come from all corners of the globe. Intellectually, our interests span the breath of the field of education. The Conference is a site of critical reflection, both by leaders in the field and emerging scholars and teachers. Those unable to attend the Conference may opt for virtual participation in which community members can either or both submit a video or slide presentation with voiceover, or simply submit a paper for peer review and possible publication in the Journal.

Online presentations can be viewed on YouTube.

\section{Publishing}

The Learner Community enables members to publish through three mediums.

First, by participating in the Learning Conference, community members can enter a world of journal publication unlike the traditional academic publishing forums - a result of the responsive, non-hierarchical and constructive nature of the peer review process. The International Journal of Learning provides a framework for double-blind peer review, enabling authors to publish into an academic journal of the highest standard.

The second publication medium is through the book series The Learner, publishing cutting edge books on education in print and electronic formats. Publication proposals and manuscript submissions are welcome.

The third major publishing medium is our news blog, constantly publishing short news updates from the Learner Community, as well as major developments in the field of education. You can also join this conversation at Facebook and Twitter or subscribe to our email Newsletter. 


\section{Common Ground Publishing Journals}

\begin{tabular}{|c|c|}
\hline $\begin{array}{l}\text { AGING } \\
\text { Aging and Society: An Interdisciplinary Journal } \\
\text { Website: http://AgingAndSociety.com/journal/ }\end{array}$ & $\begin{array}{c}\text { ARTS } \\
\text { The International Journal of the Arts in Society. } \\
\text { Website: www.Arts-Journal.com }\end{array}$ \\
\hline $\begin{array}{c}\text { BOOK } \\
\text { The International Journal of the Book } \\
\text { Website: www.Book-Journal.com }\end{array}$ & $\begin{array}{c}\text { CLIMATE CHANGE } \\
\text { The International Journal of Climate Change: } \\
\text { Impacts and Responses } \\
\text { Website: www.Climate-Journal.com }\end{array}$ \\
\hline $\begin{array}{c}\text { CONSTRUCTED ENVIRONMENT } \\
\text { The International Journal of the } \\
\text { Constructed Environment } \\
\text { Website: www.ConstructedEnvironment.com/journal }\end{array}$ & $\begin{array}{c}\text { DESIGN } \\
\text { Design Principles and Practices: } \\
\text { An International Journal } \\
\text { Website: www.Design-Journal.com }\end{array}$ \\
\hline $\begin{array}{c}\text { DIVERSITY } \\
\text { The International Journal of Diversity in } \\
\text { Organizations, Communities and Nations } \\
\text { Website: www.Diversity-Journal.com }\end{array}$ & $\begin{array}{l}\text { FOOD } \\
\text { Food Studies: An Interdisciplinary Journal } \\
\text { Website: http://Food-Studies.com/journal/ }\end{array}$ \\
\hline $\begin{array}{c}\text { GLOBAL STUDIES } \\
\text { The Global Studies Journal } \\
\text { Website: www.GlobalStudiesJournal.com }\end{array}$ & $\begin{array}{c}\text { HEALTH } \\
\text { The International Journal of Health, } \\
\text { Wellness and Society } \\
\text { Website: www.HealthandSociety.com/journal }\end{array}$ \\
\hline $\begin{array}{c}\text { HUMANITIES } \\
\text { The International Journal of the Humanities } \\
\text { Website: www. Humanities-Journal.com }\end{array}$ & $\begin{array}{c}\text { IMAGE } \\
\text { The International Journal of the Image } \\
\text { Website: www.Onthelmage.com/journal }\end{array}$ \\
\hline $\begin{array}{l}\text { LEARNING } \\
\text { The International Journal of Learning. } \\
\text { Website: www.Learning-Journal.com }\end{array}$ & $\begin{array}{c}\text { MANAGEMENT } \\
\text { The International Journal of Knowledge, } \\
\text { Culture and Change Management. } \\
\text { Website: www.Management-Journal.com }\end{array}$ \\
\hline $\begin{array}{c}\text { MUSEUM } \\
\text { The International Journal of the Inclusive Museum } \\
\text { Website: www.Museum-Journal.com }\end{array}$ & $\begin{array}{c}\text { RELIGION AND SPIRITUALITY } \\
\text { The International Journal of Religion and } \\
\text { Spirituality in Society } \\
\text { Website: www.Religion-Journal.com }\end{array}$ \\
\hline $\begin{array}{c}\text { SCIENCE IN SOCIETY } \\
\text { The International Journal of Science in Society } \\
\text { Website: www.ScienceinSocietyJournal.com }\end{array}$ & $\begin{array}{c}\text { SOCIAL SCIENCES } \\
\text { The International Journal of Interdisciplinary } \\
\text { Social Sciences } \\
\text { Website: www.SocialSciences-Journal.com }\end{array}$ \\
\hline $\begin{array}{c}\text { SPACES AND FLOWS } \\
\text { Spaces and Flows: An International Journal of } \\
\text { Urban and ExtraUrban Studies } \\
\text { Website: www.SpacesJournal.com }\end{array}$ & $\begin{array}{c}\text { SPORT AND SOCIETY } \\
\text { The International Journal of Sport and Society } \\
\text { Website: www.sportandsociety.com/journal }\end{array}$ \\
\hline $\begin{array}{c}\text { SUSTAINABILITY } \\
\text { The International Journal of Environmental, Cultural, } \\
\text { Economic and Social Sustainability } \\
\text { Website: www.Sustainability-Journal.com }\end{array}$ & $\begin{array}{c}\text { TECHNOLOGY } \\
\text { The International Journal of Technology, } \\
\text { Knowledge and Society } \\
\text { Website: www.Technology-Journal.com }\end{array}$ \\
\hline $\begin{array}{c}\text { UBIQUITOUS LEARNING } \\
\text { Ubiquitous Learning: An International Journal } \\
\text { Website: www.ubi-learn.com/journal/ }\end{array}$ & $\begin{array}{l}\text { UNIVERSITIES } \\
\text { Journal of the World Universities Forum } \\
\text { Website: www.Universities-Journal.com }\end{array}$ \\
\hline
\end{tabular}

